\title{
CONTRIBUTION TO THE KNOWLEDGE OF CYLINDROCNEMA PLANA MAYR, 1864 (HEMIPTERA: HETEROPTERA: ACANTHOSOMATIDAE)
}

\author{
CONTRIBUCIÓN AL CONOCIMIENTO DE CYLINDROCNEMA PLANA MAYR, 1864 \\ (HEMIPTERA: HETEROPTERA: ACANTHOSOMATIDAE)
}

\author{
Eduardo I. Faúndez ${ }^{1.2} \&$ Giannina A. Osorio ${ }^{2}$
}

Acanthosomatidae is a family of Heteroptera, commonly named "shield bugs", which is one of the least diversified families within Pentatomoidea, containing near 200 species classified in 47 genera (Kment 2005). Currently, there are 12 valid species of Acanthosomatidae in Chile, and much of those are poorly known.

Cylindrocnema plana Mayr, 1864 seems to be a rare species. It is easy to identify from other Ditomotarsinae by its thickened antennal segments. This species was described on basis of one male specimen from Chiloé Island in southern Chile and little information have been published lately.

\section{Notes on taxonomy}

Cylindrocnema plana Mayr, 1864

[Cylindrocnema plana Mayr, 1864: 913,

Type material: $10^{7}$ Chiloé.]

=[Nopalis crassicornis Reed, 1898: 156-157.

Type material: 2 unsexed specimens, Chiloé.]

Reed (1898) described Nopalis crassicornis from Chiloé Island, and posteriorly Froeschner (1978) examined the type (one specimen is lost) of this species and placed it as junior synonym of $C$. plana. Prado (2008) listed Nopalis crassicornis, as junior synonym of $C$. plana and Nopalis sulcatus Signoret, 1864, however, the latter is clearly a mistake and only the synonymy of Nopalis crassicornis with $C$. plana is valid.

Sinopla canaliculus Reed, 1898 nomen dubium [Sinopla canaliculus Reed, 1898:160.

Holotype: 1 unsexed specimen, Valdivia (lost).]

Prado (2008) listed Sinopla canaliculus as a junior synonym of $C$. plana, without any justification, explanation or comment. Unfortunately, the type of this species seems to be lost as many other Reed's types, and the original description is insufficient to establish the identity of the species. On the other hand, Reed (1898) described S. canaliculus in the same paper as Nopalis crassicornis, giving an identification key to Chilean Acanthosomatidae genera, which makes improbable the synonymy of these taxa (see Reed 1898: p. 137), and hence we prefer to treat Sinopla canaliculus as a nomen dubium.

\footnotetext{
${ }^{1}$ Entomon group, Entomology Laboratory, Instituto de la Patagonia, Universidad de Magallanes, Avenida Bulnes 01855 Punta Arenas, Chile, P.O. Box 113-D.

${ }^{2}$ Centro de Estudios en Biodiversidad (CEBCh), Avenida Diego Portales 901, Osorno, Chile.

ed.faundez@gmail.com; giannina.osorio@gmail.com.
} 


\section{Distribution}

There are scarse data on the distribution of Cylindrocnema plana. Bredin (1898) and $\mathrm{Ku}-$ mar (1974) gave records only from Chiloé Island (42 $\left.30^{\circ} \mathrm{S}-73^{\circ} 55^{\prime} \mathrm{W}\right)$ in southern Chile; which is the type locality of both $C$. plana and N. crassicornis, and the only known Chilean locality so far. Kormilev (1950) described the female with material from Hua Hum (4006'S-71 ${ }^{\circ} 39^{\prime} \mathrm{W}$ ) in Argentina. Here we add new Chilean records which extend the north distribution range of this species, together with the first biological information:

\section{Material examined}

Chile: Bío Bío Region, Las Trancas (36 $54^{\prime}$ S-71'29' W), 6 to 14 - II - 2007, ex Nothofagus dombeyi, R. Honour leg. 1 \& [E. Faúndez collection]; Maule Region, Altos de Vilches ( $35^{\circ} 35^{\prime} \mathrm{S}-71^{\circ} 02^{\prime} \mathrm{W}$, 1400-1800 m a.s.l.), 14 to 16 - I-2005, Bílý S. leg. $10^{7}$ Petr Kment det. [National Museum of Prague collection].

Host plant. Nothofagus dombeyi (Mirb.) Oerst. (Nothofagaceae).

\section{Comments}

Cylindrocnema plana is the second Acanthosomatidae species reported on Nothofagus dombeyi, together with Acrophyma cumingii (Westwood, 1837) (Faúndez 2009a). Additional Acanthosomatidae species have been cited on other Nothofagus species: Sinopla perpunctatus Signoret, 1864 (see Faúndez 2009b), Lanopis rugosus Signoret, 1864 (China 1962), and Ditomotarsus punctiventris Spinola, 1852 (Faúndez 2007a). However, only S. perpunctatus and $D$. punctiventris have been well studied. Ditomotarsus punctiventris shows generalist habits and can be found outside of the Nothofagus forests. On the other hand, S. perpunctatus is a specialist restricted to Nothofagus spp., with preference for $N$. antarctica, and its distribution range is restricted to the area of Nothofagus forests (see Faúndez 2007b, Osorio 2009).

According to the new data presented here, we believe that the host preferences of $C$. plana are probably similar to $S$. perpunctatus - its distribution coincides with the Nothofagus forests, and it was found on $N$. dombeyi, a species present across the known distributional range of $C$. plana. However, further research is needed in order to know well this species and its biological and biogeographic relationships.

\section{ACKNOWLEDGEMENTS}

We thank Richard Honour for sending his Cylindrocnema plana specimen and David Rider for his bibliographic help; we also give special thanks to Petr Kment for having given us the data of the specimen deposited in the National Museum, Prague, Czech Republic and making a critic reading of the text.

\section{LITERATURE CITED}

Breddin, G. 1897. Hemipteren. In: Hamburger Magelaensischen Sammelreise. Zweite Lieferung, $\mathrm{N}^{\circ}$ 4. Hamburg. $36+2 \mathrm{pp}$.

China, W. E. 1962. Hemiptera-Heteroptera collected by the Royal Society expedition to South Chile 1958-1959. Annals and Magazine of Natural History, Series 13, 5 (1963): 705-723.

Faúndez, E. I. 2007a. Notes on the biology of Ditomotarsus punctiventris Spinola, 1852 (Hemiptera: Acanthosomatidae) in the Magellan region, and comments about the crypsis in Acanthosomatidae. Anales Instituto Patagonia (Chile) 35(2): 67-70.

Faúndez, E. I. 2007b. Nuevos registros para Sinopla perpunctatus Signoret, 1863 (Hemiptera: Acanthosomatidae) en Chile. Boletín de la Sociedad Entomológica Aragonesa. 41: 368.

Faúndez, E. I. 2009a. Contribution to the knowledge of the genus Acrophyma Bergroth, 1917 (Hemiptera: Heteroptera: Acanthosomatidae). Zootaxa, 2137: 57-65.

Faúndez, E. I. 2009b. Sinopla perpunctatus Signoret, 1864 or Sinopla perpunctata Signoret, 1864? A problematic name for a South American shield bug (Hemiptera: Heteroptera: Acanthosomatidae). Boletín de la Sociedad Entomológica Aragonesa, 44: 553-554.

Froeschner, R. C. 1978. Cylindrocnema plana Mayr, 1864 , a senior synonym of Nopalis crassicornis (Reed), 1898 (Hemiptera: Acanthosomatidae). Proceedings of the Entomological Society of Washington, 80(1): 130-131.

Kment, P. 2005. Revision of the genus Mahea Distant, 1909 (Insecta: Heteroptera: Acanthosomatidae), with review of the Acanthosomatidae of Madagascar and Seychelles. Acta Entomo- 
logica Musei Nationalis Pragae, 45: 21-50. Kormilev, N. A. 1950. Notas hemipterológicas. Acta Zoologica Lilloana, 9: 495-503.

Kumar, R. 1974. A revision of world Acanthosomatidae (Heteroptera: Pentatomoidea): Keys to and descriptions of subfamilies, tribes and genera, with designation of types. Australian Journal of Zoology, Supplementary Series, 34: 1-60.

Mayr, G. L. 1864. Diagnosen neuer Hemipteren. Verhandlungen des Zoologisch-Botanischen Gesellschaft in Wien, 14:903-914.

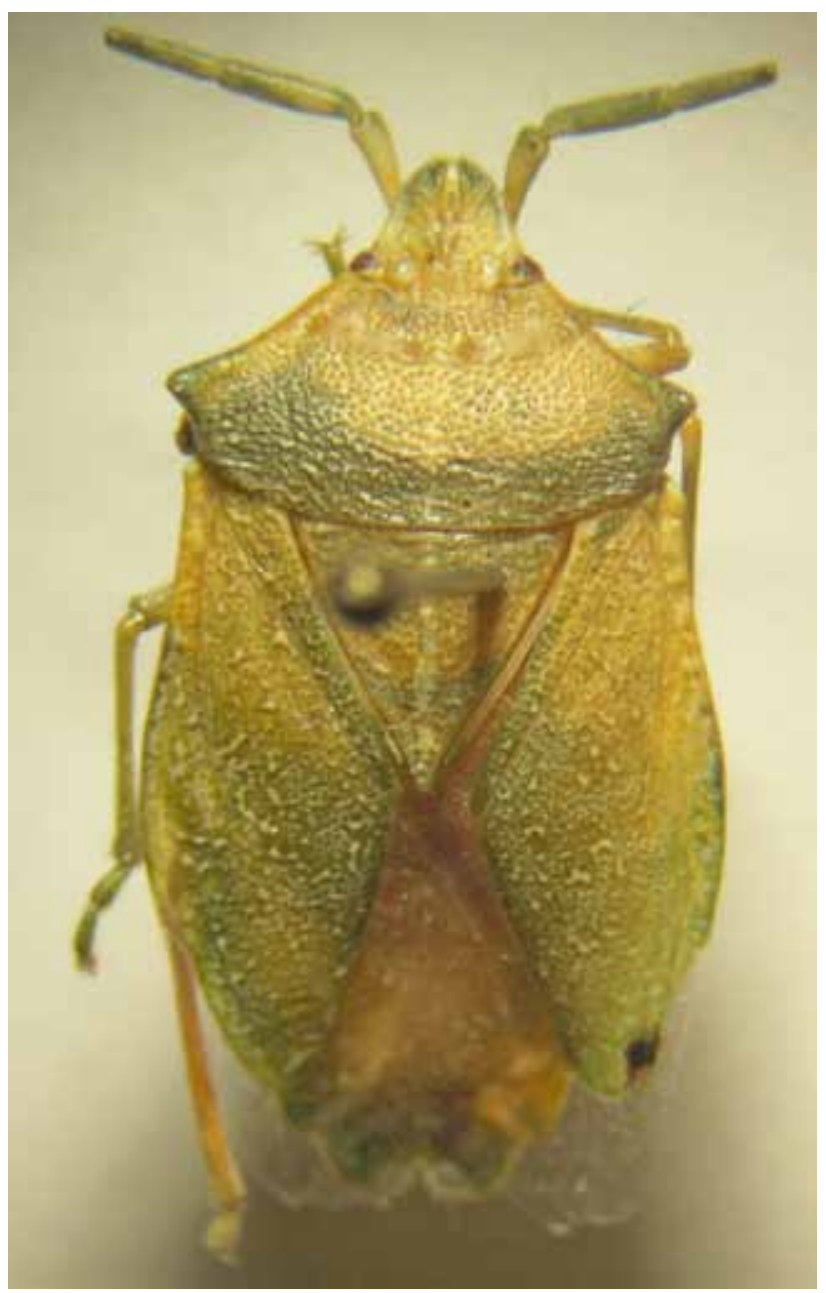

Fig. 1. Cylindrocnema plana Mayr, 1864, habitus (specimen from Las Trancas).
Osorio, G. A. 2009. Primer registro para la Región del Maule de Sinopla perpunctatus Signoret, 1864 (Hemiptera: Heteroptera: Acanthosomatidae). Boletín de Biodiversdidad de Chile, 1(1): 35-37.

Prado C, E. 2008. Conocimiento actual de Hemiptera - Heteroptera de Chile con lista de especies. Boletín del Museo Nacional de Historia Natural, Chile, 57: 31-75.

Reed, E. C. 1898. Sinopsis de los hemípteros de Chile. Primera parte: Heterópteros. Revista Chilena de Historia Natural, 2(12): 153-160.

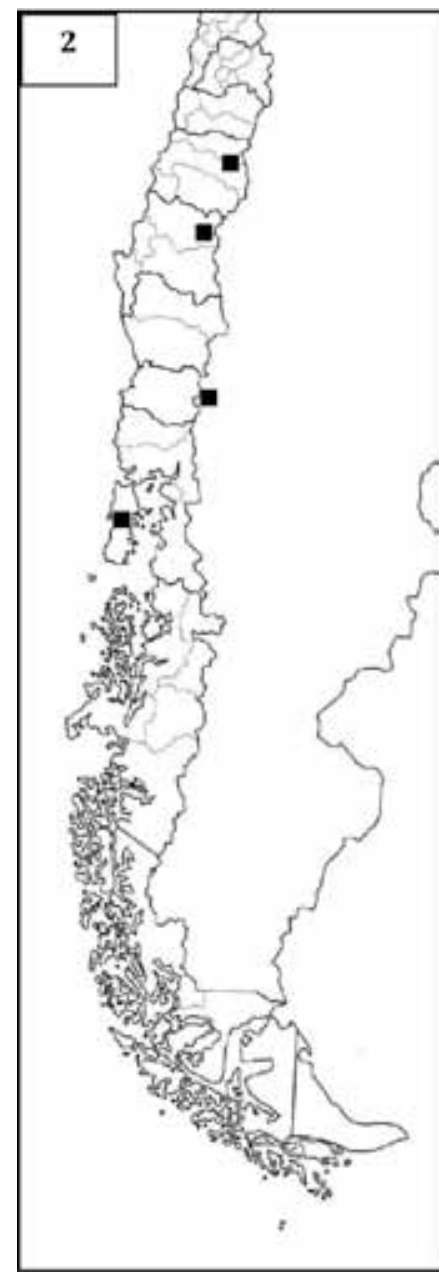

Fig. 2. Distribution of Cylindrocnema plana. 